\title{
DAMPAK PROGRAM SEKOLAH LAPANG PENGELOLAAN TANAMAN TERPADU TERHADAP EFISIENSI TEKNIS USAHATANI KEDELAI DI KABUPATEN JEMBER
}

\author{
Indah Ibanah1, Andriyono Kilat Adhi ${ }^{2}$ dan Dwi Rachmina ${ }^{2}$ \\ 1)Mahasiswa Program Studi Magister Sains Agribisnis, \\ Departemen Agribisnis, Fakultas Ekonomi dan Manajemen IPB \\ 2)Departemen Agribisnis, Fakultas Ekonomi dan Manajemen, Institut Pertanian Bogor \\ e-mail : 1)ibanahindah.88@gmail.com
}

\begin{abstract}
This study aimed to analyze the impact of Sekolah Lapang Pengelolaan Tanaman Terpadu (SLPTT) on technical efficiency soybean participants and non-participants farmers. SLPTT is one of the government programs in an effort to enhancement production and productivity of soybean through the process of learning the application of technology to the management of the use of farm inputs and integrated climate. The method used was the Stochastic Frontier Analysis (SFA) with a model of the Cobb-Douglas production function. Location research in Jember Regency, East Java.

The results show the factors that influence significantly to the enhancement in soybean production among others, land, seeds, chemical fertilizers, and pesticides liquid. Production factors most responsive to the enhancement in soybean production is the amount of seed used. The average level of technical efficiency of soybean farming both farmers SLPTT or non SLPTT in Jember Regency have technically efficient. However, farmers SLPTT has an average value of technical efficiency is higher than their non SLPTT, respectively worth 0.83 and 0.75 . The sources that affect farmers' socio-economic enhancement of technical efficiency of soybean farming significantly among others, age, planting techniques, the use of VUB, mechanical control, and the number of counseling or SLPTT 2013.
\end{abstract}

Keywords: technical efficiency, SLPTT, stochastic frontier, and soybean

\section{PENDAHULUAN}

\section{LATAR BELAKANG}

Kedelai (Glicine max (L.) Merill) merupakan tanaman kacang-kacangan yang memiliki sumber gizi seperti, protein nabati tinggi, lemak, vitamin, dan mineral yang sering dikonsumsi oleh semua lapisan masyarakat Indonesia. Oleh sebab itu, kedelai digunakan sebagai bahan baku berbagai industri pangan dan non pangan.

Seiring dengan pertumbuhan jumlah penduduk Indonesia dan perubahan pola makanan bergizi, mengindikasikan konsumsi kedelai semakin meningkat, sehingga kebutuhan akan kedelai juga meningkat. Hal ini didukung oleh pernyataan Kementerian Pertanian (2013) yang menyatakan kebutuhan kedelai di dalam negeri sebesar 2,4 juta ton per tahun dan 70 persen dari kebutuhan kedelai nasional tersebut berasal dari kedelai impor ${ }^{1}$.

Kekurangan dan ketidakmampuan produksi kedelai domestik dalam memenuhi kebutuhan kedelai yang terus meningkat ini, membuat pemerintah tetap melakukan impor kedelai (Harsono, 2008). Ketergantungan terhadap impor salah satunya dikarenakan produktivitas kedelai Indonesia yang hanya mampu mencapai 1,5 ton per ha. Hal ini dinilai belum mampu menghasilkan produksi kedelai secara optimal bila berpatokan pada Amerika Serikat yang mampu memproduksi setiap hektar lahan sebesar 3-3,5 ton. Selain itu, suatu penelitian yang dilakukan pemerintahan Indonesia membuktikan produksi kedelai Indonesia sebenarnya mampu men-

${ }^{1}$ Dani RR. 2013. Mentan Suswono: 70 persen Kebutuhan Kedelai di Indonesia dari Impor.

http:/ / finance.detik.com/read/2013/09/rogram 16/185357/2360418/1036/ [diakses pada 2014 Januari 15] 
capai 2-2,5 ton per ha (Dinas Pertanian, 2008). Berdasarkan data BPS (2013), diketahui

Upaya menekan laju impor kedelai melalui berbagai strategi, yaitu peningkatan produktivitas, perluasan areal tanam, peningkatan efisiensi produksi, penguatan kelembagaan petani, peningkatan kualitas dan nilai tambah produk, perbaikan akses pasar dan sistem permodalan, pengembangan infrastruktur, serta pengaturan tataniaga dan insentif usaha. Mengingat penduduk Indonesia cukup besar dan industri pangan berbahan baku kedelai berkembang pesat maka pengembangan kedelai perlu mendapat prioritas dalam pembangunan pertanian nasional.

Pemerintah seiring melakukan kebijakan impor kedelai juga membuat suatu program pada pengelolaan usahatani kedelai, salah satunya melalui program Sekolah Lapang Pengelolaan Tanaman Terpadu (SLPTT). SLPTT merupakan proses belajar mengajar bagi petani dalam hal teknik budidaya dengan mengkaji bersama berdasarkan spesifik lokasi dan menerapkan berbagai teknologi usahatani melalui pendekatan pengelolaan lahan, air, tanaman, organisme penganggu tanaman (OPT), dan iklim secara terpadu, serta berkelanjutan. Program SLPTT sebagai salah satu solusi adopsi teknologi dalam penggunaan input untuk mencapai efisiensi teknis dalam aspek manajerial input. Selain itu, program SLPTT berprinsip pada spesifik lokasi dalam pengelolaan tanaman. Dengan demikian, melalui program SLPTT petani diharapkan mampu mengelola penggunaan faktor produksi (input) dengan baik dan peningkatan produksi dan produktivitas tercapai (Direktorat Jenderal Tanaman Pangan, 2012).

Jawa Timur merupakan sentra utama produksi kedelai nasional. Namun, berdasarkan data BPS (2013) diketahui produktivitasnya lebih rendah dibanding Jawa Tengah yang memiliki luas panen kedelai lebih rendah. Rata-rata luas panen kedelai terluas adalah di Provinsi Jawa Timur, yaitu 235581.83 ha dengan rata-rata produksi terbesar juga, yaitu 339716 ton. Namun, rata- rata produktivitas kedelai terbesar berada di Provinsi Jawa Tengah sebesar 1555.03 kg per ha yang hanya memiliki rata-rata luas panen 97274 ha. Produktivitas tertinggi bukan pada luas areal tanaman kedelai di Provinsi Jawa Timur. Hal ini membuktikan bahwa luas areal tanam tidak memberikan keterjaminan terhadap hasil produktivitas.

Semakin luas lahan yang diusahakan, maka produksi akan semakin meningkat. Namun, peningkatan luas lahan belum tentu meningkatkan produktivitas. Menurut Tinaprilla (2012) ukuran usahatani (farm size) berbeda dengan skala usahatani. Semakin besar skala usahatani, maka akan semakin efisien. Namun, tidak demikian dengan ukuran usahatani. Selain itu, kondisi yang demikian diindikasikan penggunaan input dan faktor internal petani dalam kegiatan usahatani di Jawa Timur kurang efisien.

Menurut Coelli et al. (2005), indikator produktivitas dapat dilihat melalui tingkat efisien secara teknis. Selain itu, berdasarkan penelitian Elibariki et al. (2008) menyatakan peningkatan produktivitas tidak hanya dapat dicapai melalui penambahan input dan adopsi inovasi teknologi, tetapi juga melalui penggunaan input yang lebih efisien dan keterampilan di tingkat petani (faktor determinan sosio-ekonomi). Efisiensi teknis adalah ukuran keberhasilan usahatani dinilai dari output yang maksimal dengan penggunaan input tertentu (Farell, 1957).

Pada penelitian ini dampak SLPTT terhadap efisiensi teknis usahatani kedelai dapat diketahui melalui perbandingan with and without, dimana perbandingan tersebut merupakan perbandingan rata-rata tingkat efisiensi teknis petani kedelai peserta SLPTT dan non SLPTT yang memiliki teknologi spesifikasi lokasi yang sama terhadap jenis sawah yang dimanfaatkan dengan sistem tanam monokultur. Selain itu, teknologi yang digunakan oleh petani SLPTT dan non SLPTT meliputi komponen SLPTT. Komponen SLPTT terdiri dari komponen pilihan dan dasar.

Komponen pilihan SLPTT yang digunakan sesuai dengan daerah penelitian, antara- 
lain: penyiapan lahan, penggunaan pupuk kimia, dan penggunaan pupuk organik. Komponen dasar SLPTT, antara lain: penggunaan Varietas Unggul Baru (VUB), penggunaan benih bermutu dan berlabel, teknik tanam tugal atau sebar, pengendalian organisme pengganggu tanaman secara terpadu dalam pengendalian mekanis atau fisik.

Dengan demikian, perlunya meneliti faktor produksi dan tingkat efisiensi teknis kedelai bagi petani kedelai peserta SLPTT dan non SLPTT pada tahun 2013. Berdasarkan uraian latar belakang dan perumusan masalah, maka research question penelitian ini sebagai berikut:

1. Apa saja faktor produksi yang mempengaruhi peningkatan produksi usahatani kedelai?

2. Apakah usahatani kedelai sudah efisien, berapa tingkat efisiensi teknisnya, dan apakah ada perbedaan tingkat efisien teknis bagi petani yang mengikuti SLPTT dan non SLPTT?

3. Apa saja faktor determinan sosio-ekonomi petani yang memengaruhi peningkatan efisiensi teknis?

\section{TUJUAN}

Berdasarkan latar belakang, perumusan masalah, dan research questions yang telah diuraikan pada sub bab sebelumnya, maka penelitian ini bertujuan:

1. Menganalisis dan menentukan faktor produksi yang memengaruhi peningkatan produksi kedelai.

2. Menganalisis dan menentukan tingkat rata-rata efisiensi teknis petani SLPTT dan non SLPTT.

3. Menganalisis dan menentukan faktorfaktor determinan sosio-ekonomi yang memengaruhi peningkatan efisiensi teknis usahatani kedelai.

\section{METODE PENELITIAN}

\section{LOKASI DAN WAKTU PENELITIAN}

Pemilihan lokasi penelitian dilakukan secara purposive di Kabupaten Jember. Dasar pemilihan ini dikarenakan Kabupaten Jember terletak di Provinsi Jawa Timur yang merupakan sentra produksi kedelai utama nasional. Pemilihan lokasi selanjutnya dipilih 2 kecamatan, yaitu Kecamatan Bangsalsari dan Kecamatan Rambipuji. Kedua lokasi tersebut dipilih karena keduanya termasuk pada 5 kecamatan sentra produksi kedelai di Kabupaten Jember dengan kesamaan sistem penanaman monokultur pada lahan sawah.

Pengumpulan data dilakukan pada bulan Februari-April 2014. Data yang diambil merupakan data input dan output usahatani kedelai kuning pada MK II tahun 2013 dengan sistem penanaman monokultur.

\section{METODE PENGAMBILAN CONTOH}

Metode penentuan pengambilan petani contoh atau responden menggunakan purposive sampling pada lokasi penelitian atas dasar kesamaan sistem penanaman kedelai monokultur pada lahan sawah dan kesediaan untuk diwawancarai bagi petani kedelai peserta SLPTT dan non SLPTT. Diperoleh 100 petani dengan komposisi masing-masing 50 petani SLPTT dan non SLPTT yang dapat merepresentatifkan keadaan di lapang.

\section{METODE ANALISIS DATA}

Metode analisis data yang digunakan adalah Stochastic Frontier Analysis (SFA). Penggunaan SFA berimplikasi pada pilihan bentuk fungsional. Analisis fungsi produksi stochastic frontier dapat digunakan untuk mengukur dan mengestimasi efisiensi produksi dari usahatani kedelai pada sisi output, sekaligus inefisiensi effect (faktor determinan sosio-ekonomi). 
Data yang terkumpul ditabulasi pada Microsoft Excel, kemudian diolah menggunakan program SAS 9.6 dan FRONTIER 4.1 dengan menggunakan metode ekonometrika, penentuan model matematis yang digunakan merupakan tahap yang menentukan hasil dari penelitan ini. Model yang digunakan merupakan abstraksi dari keadaan lokasi penelitian usahatani kedelai di Kabupaten Jember sebenarnya. Selain itu adanya analisis statistik deskriptif pada data tabulasi di Microsoft Excel.

\section{Analisis Fungsi Produksi Stochastic Frontier}

Fungsi produksi usahatani kedelai pada penelitian ini menggunakan fungsi produksi stochastic frontier production function dengan model yang dikembangkan oleh Coelli et al. (2005) dengan persamaan model CobbDouglas. Selain itu, dasar pemilihan model Cobb-Douglas karena, persamaannya dapat diubah menjadi bentuk linier berganda dan koefisien pada persamaan, sekaligus menunjukkan elastisitas $X$ (faktor produksi) terhadap Y (produksi). Persamaan CobbDouglas yang dilogaritmakan dan diubah bentuk fungsinya menjadi fungsi linear, maka terdapat asumsi dan syarat-syarat yang harus dipenuhi sebelum digunakan, antara lain:

1. Tidak ada nilai pengamatan yang bernilai nol karena logaritma dari nol adalah suatu bilangan yang besarnya tidak diketahui.

2. Terdapat asumsi bahwa tidak ada perbedaan teknologi pada setiap pengamatan dalam fungsi produksi. Maksudnya, jika fungsi produksi Cobb-Douglas yang dipakai sebagai model dalam suatu pengamatan dan bila diperlukan analisis yang memerlukan lebih dari satu model, maka perbedaan model tersebut terletak pada intersep dan bukan pada kemiringan garis (slope) model tersebut. Pada penelitian ini persamaan Cobb-Douglas menggunakan satu model dengan dasar persamaan teknologi pada sistem monokultur untuk petani SLPTT dan non SLPTT.
3. Setiap variabel bebas adalah perfect competition.

4. Perbedaan lokasi (pada fungsi produksi) seperti iklim sudah tercakup pada faktor kesalahan (error term).

Fungsi Cobb-Douglas juga memiliki kelemahan yang perlu diperhatikan, antara lain:

1. Asumsi bahwa teknologi dianggap netral, padahal belum tentu teknologi di daerah penelitian adalah sama.

2. Sampel dianggap price takers, petani menerima harga yang ditentukan di pasar, padahal untuk sampel petani yang subsisten, mungkin tidak terlalu seperti itu.

3. Tidak ada produksi (Y) maksimum, artinya sepanjang kombinasi input $(X)$ dinaikkan, maka produksi (Y) akan terus naik sepanjang expansion path-nya.

4. Elastisitas produksi tetap.

Tahap awal dari pembentukan model untuk menentukan faktor produksi yang diduga memengaruhi peningkatan produksi pada usahatani kedelai adalah penentuan variabel. Variabel yang ditentukan ada 2 macam, yaitu variabel bebas dan variabel terikat. Variabel terikat pada penelitian ini adalah jumlah produksi kedelai pada MK II oleh petani SLPTT dan non SLPTT (Y). Variabel bebas yang digunakan merupakan faktor input usahatani kedelai $(X)$ dengan pertimbangan bahwa variabel-variabel tersebut digunakan oleh petani responden dan mempunyai pengaruh yang besar terhadap variasi produksi dengan menggunakan model Cobb-Douglas. Variabel bebas yang diperoleh ada 7 input produksi dan dimasukkan pada persamaan (1) berikut ini:

$$
\begin{aligned}
& Y=B_{0} X_{1}{ }^{\beta 1} X_{2}{ }^{\beta 2} X_{3}{ }^{\beta 3} X_{4}{ }^{\beta 4} X_{5}{ }^{\beta 5} \\
& X_{6}{ }^{\beta 6} X_{7} X_{7}{ }^{\beta 7} \mathrm{e}^{\text {vi-ui. }}
\end{aligned}
$$

dimana:

$\mathrm{Y}=$ jumlah produksi petani kedelai SLPTT dan non SLPTT

$\beta_{0}=$ intersep 
$\beta_{\mathrm{n}} \quad=$ parameter penduga variabel ke-i dan merupakan elastisitas $(\mathrm{n}=1,2,3, \ldots, 7)$

$\mathrm{X}_{\mathrm{n}} \quad=$ faktor produksi yang digunakan $(\mathrm{n}=$ $1,2,3, \ldots, 7)$

e $\quad=$ bilangan natural (2.718)

vi-ui = error term $\left(\mathrm{v}_{\mathrm{i}}\right.$ adalah noise effect, $\mathrm{u}_{\mathrm{i}}$ adalah efek inefisiensi teknis model)

Pendugaan dalam mengestimasi atau mengalisis pada penelitian ini akan lebih mudah, bila persamaan diubah menjadi linier berganda dengan cara melogaritmakan persamaan (1). Bentuk linier dari fungsi produksi Cobb-Douglas persamaan sebagai berikut:

$$
\begin{array}{r}
\ln Y=\ln \beta_{0}+\beta_{1} \ln X_{1}+\beta_{2} \ln X_{2}+\beta_{3} \\
\ln X_{3}+\beta_{4} \ln X_{4}+\beta_{5} \ln X_{5}+\beta_{6} \\
\ln X_{6}+\beta_{7} \ln X_{7}+\left(v_{i}-u_{i}\right) \ldots \ldots \ldots . . .
\end{array}
$$

dimana:

Y = hasil produksi kedelai $(\mathrm{kg})$ SLPTT dan non SLPTT

$\beta_{0} \quad=$ intersep atau konstanta

$\beta_{\mathrm{i}} \quad=$ koefisien variabel $(\mathrm{i}=1,2,3, \ldots 7)$

$\mathrm{X}_{1}=$ luas tanam kedelai (ha)

$X_{2}=$ jumlah benih kedelai $(\mathrm{kg})$

$X_{3}=$ jumlah penggunaan pupuk kimia $(\mathrm{kg})$

$\mathrm{X}_{4} \quad=$ jumlah pupuk organik $(\mathrm{kg})$

$\mathrm{X}_{5} \quad=$ jumlah penggunaan pestisida cair (ml)

$\mathrm{X}_{6} \quad=$ jumlah penggunaan ZPT (gr)

$\mathrm{X}_{7} \quad=$ jumlah penggunaan tenaga kerja (HOK)

$\mathrm{v}_{\mathrm{i}}-\mathrm{u}_{\mathrm{i}}=$ error term $\left(v_{i}\right.$ adalah noise effect, $u_{i}$ adalah efek inefisiensi teknis model)

Nilai koefisien pada model pembangun ini bernilai lebih besar dari angka nol (0) atau $\beta_{1}, \beta_{2}, \beta_{3}, \ldots, \beta_{7}>0$, artinya hasil pendugaan fungsi produksi fungsi produksi stochastic frontier memberikan nilai parameter dugaan yang bernilai positif.

Keuntungan lain dalam penggunaan fungsi produksi Cobb Douglas adalah nilai parameter dari masing-masing faktor produksi yang diduga merupakan pendugaan nilai elastisitas. Jumlah elastisitas dari dari masing-masing faktor produksi yang diduga merupakan pendugaan skala usaha atau return to scale $\left(\beta_{1}+\beta_{2}+\beta_{3} \ldots+\beta_{7}\right)$. Jika $\Sigma \beta_{\mathrm{j}}=1$ berarti kegiatan produksi dalam keadaan constant return to scale (CRTS) atau dalam skala usaha yang tetap. Jika $\Sigma \beta_{\mathrm{j}}>1$ berarti kegiatan produksi dalam keadaan increasing return to scale (IRTS) atau skala usaha yang meningkat. Jika $\Sigma \beta_{\mathrm{j}}<1$ berarti kegiatan produksi dalam keadaan decreasing return to scale (DRTS) atau skala usaha yang semakin menurun. Jika $\Sigma \beta \mathrm{j}$ $\neq 1$, maka belum tentu bahwa kegiatan produksi tidak berada dalam keadaan CRTS. Perlu diuji terlebih dahulu dengan menggunakan uji F Tintner yang dirumuskan sebagai berkut:

$$
\begin{array}{r}
\text { F Tintner }=\left[\left(\sum \mathbf{e}_{2}{ }^{2}-\Sigma \mathrm{e}_{1}{ }^{2}\right) / \mathrm{m}\right] / \\
\quad\left[\left(\sum \mathrm{e}_{1}^{2}\right) /(\mathrm{n}-\mathrm{k})\right] \ldots \ldots \ldots \ldots \ldots \ldots \ldots \ldots \ldots \ldots \ldots \ldots \ldots \ldots \ldots \ldots \ldots \ldots \ldots
\end{array}
$$

dimana:

$\Sigma \mathrm{e}_{2}{ }^{2}=$ jumlah kuadrat sisa fungsi CobbDouglas

$\Sigma \mathrm{e}_{1}{ }^{2}=$ jumlah kuadrat sisa fungsi model yang diretriksi

$\mathrm{k}=$ jumlah variabel (include intercept)

$\mathrm{n} \quad$ = jumlah sampel

Metode pendugaan awal pada fungsi produksi stochastic frontier dengan menggunakan fungsi produksi Cobb Douglas ditentukan dengan metode kuadrat terkecil atau ordinary least square (OLS), sehingga ada beberapa asumsi Cobb-Dauglas yang digunakan dalam menguji kelayakan model. OLS akan menduga parameter $\beta_{\mathrm{i}}$ menggunakan software SAS 9.6 untuk memeriksa adanya pelanggaran asumsi (multicolienarity, autocorellation, dan heteroschedasticity), produksi tidak ada dalam pemodelan yang diduga. Kesesuaian model penduga dengan data yang digunakan (goodness of fit) diuji berdasarkan koefisiensi determinasi dan signifikansi parameter penduga secara bersama. Jika hipotesis diterima, maka model produksi ratarata cukup mewakili.

\section{Analisis Efisiensi Teknis dan Efek Inefisiensi Teknis}

Efisiensi teknis dapat diukur dengan menggunakan pendekatan dari sisi output dan sisi input. Pengukuran efisiensi teknis dari sisi output (indeks efisiensi Timmer) 
merupakan rasio dari output observasi terhadap output batas (frontier). Indeks efisiensi ini digunakan sebagai pendekatan untuk mengukur efisiensi teknis di dalam analisis stochastic frontier. Pada penelitian efisiansi teknis usahatani kedelai ini, peneliti menggunakan pengukuran efisiensi teknis dari sisi input yang merupakan rasio dari input batas (frontier) terhadap input observasi.

$$
T E=\frac{E\left(Y^{*} \mid U_{i}, X_{i}\right)}{E\left(Y^{*} \mid U_{i}=0, X_{i}\right)}=E\left[\exp \left(-U_{i}\right) / \varepsilon_{i}\right]
$$

dimana:

TE = efisiensi teknis petani ke- $i$

$\exp \left(u_{i}\right)=$ nilai harapan $($ mean $)$ dari $u i$, $(0 \leq T E \leq 1)$

Nilai efisiensi teknis antara 0 dan 1 tersebut berhubungan terbalik dengan nilai inefesiensi teknis $(T E=1-T I)$ dan hanya digunakan pada fungsi yang memiliki jumlah output dan input tertentu (cross section data). Banyak hal yang menjadi penyebab tidak tercapainya efisiensi (terjadi inefisiensi). Coelli et al. (1998) membuat model efek inefisiensi teknis diasumsikan bebas dan distribusinya terpotong normal dengan variabel acak yang tidak negatif. Untuk usahatani pada tahun ke- $t$ efek inefisiensi teknis $\mu_{i t}$ diperoleh dengan pemotongan terhadap distribusi $N\left(u_{i t}, \sigma \mid\right)$, dengan rumus matematis berikut:

$$
\mathrm{u}_{\mathrm{it}}=\delta_{0}+\mathrm{z}_{\mathrm{it}} \delta+\mathrm{w}_{\mathrm{it}}
$$

dimana:

$z_{i}=$ variabel penjelas dengan ukuran $(1 \times \mathrm{M})$ yang nilainya konstan

$\delta$ = parameter skala yang dicari dengan ukuran (Mx1)

$w_{i}=$ variabel acak

Efisiensi produksi ditentukan oleh efisiensi teknis dan efisiensi alokatif, namun fungsi produksi stochastic frontier pada konsep efisiensi Farrel (1957) hanya mampu menangkap efisiensi secara teknis. Pada beberapa penelitian terdahulu dan literatur menyatakan efisiensi teknis cukup efisien jika bernilai $\geq 0,70$ dan belum efisien bernilai < 0,70 (Coelli et al., 2005).

Metode pengukuran inefisiensi teknis yang digunakan dalam penelitian ini mengacu pada model efek inefisiensi teknis yang dikembangkan oleh Coelli et al. (2005). Variabel $\mathrm{u}_{\mathrm{i}}$ ini merupakan variabel acak yang menggambarkan inefisiensi teknis di dalam fungsi produksi dan berkaitan dengan faktor eksternal, sosio ekonomi petani, dan komponen SLPTT kedelai. Semakin besar nilai $u_{i}$, maka semakin besar inefisiensi. Variabel $u_{i}$ yang digunakan untuk mengukur efek inefisiensi teknis, diasumsikan bebas dan terdistribusi normal dengan $\mathrm{N}\left(\mu \mathrm{i}, \sigma^{2}\right)$. Penentuan nilai parameter distribusi ( $\mu i)$ efek inefisiensi teknis pada penelitian ini digunakan rumus sebagai berikut:

$$
\begin{aligned}
\mathrm{u}=\delta_{0}+\delta_{1} Z_{1}+\delta_{2} Z_{2}+\delta_{3} Z_{3}+\delta_{4} Z_{4}+ \\
\delta_{5} Z_{5}+\delta_{6} Z_{6}+\delta_{7} Z_{7}+\delta_{8} Z_{8}+ \\
\delta_{9} Z_{9}+\delta_{10} Z_{10}+w_{i t} \ldots \ldots \ldots \ldots \ldots \ldots \ldots \ldots \ldots \ldots \ldots \ldots \ldots
\end{aligned}
$$

dimana:

$\mathrm{u}_{\mathrm{i}}=$ efek inefisiensi teknis petani

$\mathrm{Z}_{1}=$ usia petani (tahun)

$Z_{2}=$ lama pendidikan formal petani (tahun)

$Z_{3}=$ lama pengalaman berusahatani kedelai (tahun)

$\mathrm{Z}_{4}=$ dummy teknik tanam, dengan ketentuan dummy $\mathrm{d}_{1}$ bernilai 1 untuk petani yang menggunakan teknik tugak atau gejik dan $\mathrm{d}_{2}$ bernilai 0 untuk petani yang menggunakan teknik sebar pada kegiatan budidaya kedelai di MK II

$\mathrm{Z}_{5}=$ dummy pengguaan benih Varietas Unggul Baru (VUB), dengan ketentuan dummy $\mathrm{d}_{1}$ bernilai 1 untuk petani yang menggunakan jenis benih VUB dan $\mathrm{d}_{2}$ bernilai 0 untuk petani yang tidak menggunakan

$\mathrm{Z}_{6}=$ dummy penggunaan benih berlabel atau bersertifikat, dengan ketentuan dummy $\mathrm{d}_{1}$ bernilai 1 untuk petani yang menggunakan benih berlabel dan $\mathrm{d}_{2}$ bernilai 0 untuk petani yang tidak menggunakan

$\mathrm{Z}_{7}=$ dummy petani yang melakukan pengendalian mekanis, dengan ketentuan dummy $\mathrm{d}_{1}$ bernilai 1 untuk petani yang melakukan dan $\mathrm{d}_{2}$ bernilai 0 untuk petani yang tidak melakukan 
$\mathrm{Z}_{8}=$ jumlah kedatangan petani dalam kegiatan penyuluhan kedelai dan atau SLPTT kedelai 2013 (kali)

$\mathrm{Z}_{9}=$ dummy pernah atau tidaknya petani mengikuti penyuluhan kedelai atau SLPTT kedelai sebelum tahun 2013, dengan ketentuan dummy $\mathrm{d}_{1}$ bernilai 1 untuk petani yang pernah mengikuti dan $\mathrm{d}_{2}$ bernilai 0 untuk petani yang tidak pernah mengikuti

$\mathrm{Z}_{10}=$ jumlah modal yang diterima oleh petani (Rp)

Nilai parameter diharapkan $\delta_{2}, \delta_{3}, \delta_{4}, \delta_{5}$, $\delta_{6}, \ldots, \delta_{10}<0$. Bila nilai parameter penduga inefisiensi bernilai negatif, maka variabel tersebut menurunkan inefisiensi. Artinya, setiap peningkatan masukkan (input) akan meningkatkan efisiensi teknis usahatani kedelai dan sebaliknya untuk $\delta_{1}$ dengan nilai $>0$.

Jika $H_{0}: \gamma=\delta_{1}, \delta_{2}, \delta_{3}, \ldots$ dan $\delta_{10}=0$, artinya efek inefisiensi teknis tidak ada dalam model fungsi produksi. Jika hipotesis ini diterima, maka model fungsi produksi rata-rata sudah cukup mewakili data empiris. Nilai $\gamma$ merupakan kontribusi dari efisiensi teknis didalam efek residual total. Model estimasi nantinya menggunakan dugaan parameter Maximum Likelihood Estimation (MLE) tingkat a maksimum sebesar 1, 5, 10, dan 15 persen.

Nilai parameter $\gamma$ berkisar antara $0 \leq \gamma \leq 1$. Nilai yang mendekati satu menunjukkan bahwa error term hanya berasal dari efek inefisiensi $\left(u_{i}\right)$ dan bukan berasal dari noise $\left(\mathrm{v}_{\mathrm{i}}\right)$. Nilai parameter merupakan kontribusi dari efisiensi teknis di dalam efek residual total. Nilai yang mendekati 1 berarti error term hanya berasal dari akibat ineficiency effect $\left(\mathrm{u}_{\mathrm{i}}\right)$ dan bukan berasal dari noise effect $\left(\mathrm{v}_{\mathrm{i}}\right)$. Berbeda hal, jika mendekati nol diinterpretasikan bahwa seluruh error term adalah sebagai akibat dari noise $\left(\mathrm{v}_{\mathrm{i}}\right)$ seperti cuaca, hama, penyakit, bencana alam dan sebagainya.

Pendugaan fungsi produksi dan efek inefisiensi perlu diuji secara simultan dengan menggunakan program FRONTIER 4.1 agar terjadi kekonsistenan (Coelli, 1996). Hasil pengolahan program FRONTIER 4.1 juga menghasilkan perkiraan nilai log likelihood.

Menurut Battese and Corra 1977 dalam Coelli et al. (2005), nilai log likelihood dengan metode MLE perlu dibandingkan dengan nilai log likelihood dengan metode OLS. Jika nilai log likelihood dengan metode MLE lebih besar OLS (nilai log likelihood pada MLE > OLS), maka fungsi produksi dengan metode MLE baik dan sesuai dengan kondisi daerah penelitian. Nilai sigma square $\left(\Sigma^{2}\right)$ menunjukkan distribusi dari error term inefisiensi $\left(\mathrm{u}_{\mathrm{i}}\right)$. Jika nilainya kecil artinya $\left(\mathrm{u}_{\mathrm{i}}\right)$ terdistribusi secara normal.

Data yang terkumpul ditabulasi pada Microsoft Excel, kemudian diolah dengan menggunakan program SAS 9.6 dan FRONTIER 4.1. Pendugaan parameter fungsi produksi stochastic frontier dan ineficiency function dilakukan secara simultan dengan program FRONTIER 4.1. Pengujian parameter stochastic frontier dan efek inefisiensi teknis dilakukan dengan dua tahap. Tahap pertama merupakan pendugaan parameter $\beta_{j}$ dengan menggunakan metode Ordinary Least Squares (OLS) dengan software SAS 9.0. Tahap kedua merupakan pendugaan seluruh parameter $\beta_{j}$, $\beta_{0}$, variasi $u_{i}$ dan $v_{i}$ dengan mengunakan metode Maximum Likelihood Estimation (MLE) pada signifikasi a $1 \%, 5 \%, 10 \%$, dan $15 \%$.

\section{HASIL DAN PEMBAHASAN}

Stochastic frontier analysis (SFA) bertujuan menduga keseluruhan parameter faktor produksi, intersep, dan varians dari kedua komponen kesalahan internal $\left(\mathrm{u}_{\mathrm{i}}\right)$ dan eksternal $\left(\mathrm{v}_{\mathrm{i}}\right)$, serta tingkat efisiensi teknis pada setiap petani kedelai responden di Kabupaten Jember. Deskriptif statistik data kondisi pada lokasi penelitian ada pada Tabel 1.

Standar deviasi dan pada Tabel 1 merupakan variasi sebaran data. Semakin kecil nilai sebarannya berarti variasi nilai data makin sama Jika sebarannya bernilai 0 , maka nilai semua datanya adalah sama. Semakin besar nilai sebarannya berarti data semakin bervariasi. Diketahui nilai rata-rata variabel input atau output lebih tinggi dibanding standar deviasi. Hal ini, maka dapat disimpulkan bahwa data yang diperoleh di lapang memiliki variasi yang sama atau dikatakan data lapang homogen. 
Tabel 1. Deskripsi Statistik Data Pendugaan Fungsi Produksi Kedelai Petani SLPTT dan Non SLPTT di Kabupaten Jember tahun 2013

\begin{tabular}{|c|c|c|c|c|c|}
\hline \multicolumn{6}{|c|}{ Usahatani kedelai petani SLPTT per hektar } \\
\hline Variabel output/input & Simbol & Rata-rata & St. Deviasi & Maksimum & Minimum \\
\hline Produksi (kg) & Y & 1288.94 & 792.38 & 3730.00 & 125.00 \\
\hline Produksitivitas (kg) & Y & 1823.29 & 469.18 & 3160.00 & 933.00 \\
\hline Luas lahan (ha) & $\mathrm{X}_{1}$ & 1.00 & 0.00 & 1.00 & 1.00 \\
\hline Jumlah benih (kg) & $X_{2}$ & 53.93 & 17.87 & 120.00 & 30.00 \\
\hline Jumlah pupuk kimia (kg) & $X_{3}$ & 95.00 & 52.53 & 243.00 & 18.02 \\
\hline Jumlah pupuk organik (kg) & $\mathrm{X}_{4}$ & 570.88 & 306.34 & 1020.00 & 0.00 \\
\hline Jumlah pestisida cair $(\mathrm{ml})$ & $\mathrm{X}_{5}$ & 1554.68 & 562.84 & 3000.00 & 533.33 \\
\hline Jumlah ZPT (gr) & $\mathrm{X}_{6}$ & 20.00 & 141.42 & 1000.00 & 0.00 \\
\hline Jumlah tenaga kerja (HOK) & $X_{7}$ & 60.11 & 37.09 & 173.71 & 18.51 \\
\hline \multicolumn{6}{|c|}{ Usahatani kedelai petani non SLPTT per hektar } \\
\hline Produksi (kg) & Y & 1035.97 & 821.74 & 3500.00 & 150.00 \\
\hline Produktivitas (kg) & Y & 1673.10 & 894.70 & 4000.00 & 400.00 \\
\hline Luas lahan (ha) & $\mathrm{X}_{1}$ & 1.00 & 0.00 & 1.00 & 1.00 \\
\hline Jumlah benih (kg) & $X_{2}$ & 56.90 & 30.99 & 160.00 & 16.67 \\
\hline Jumlah pupuk kimia (kg) & $X_{3}$ & 73.41 & 103.73 & 727.53 & 0.00 \\
\hline Jumlah pupuk organik (kg) & $X_{4}$ & 47.10 & 113.92 & 500.00 & 0.00 \\
\hline Jumlah pestisida cair (ml) & $X_{5}$ & 1797.46 & 1116.10 & 6000.00 & 533.33 \\
\hline Jumlah ZPT (gr/ha) & $X_{6}$ & 52.52 & 151.67 & 761.90 & 0.00 \\
\hline Jumlah tenaga kerja (HOK) & $X_{7}$ & 59.39 & 47.66 & 212.29 & 13.22 \\
\hline
\end{tabular}

Keterangan: $1 \mathrm{HOK}=7$ jam kerja

\section{ANALISIS FUNGSI PRODUKSI USAHATANI KEDELAI DI KABUPATEN JEMBER}

Model yang digunakan untuk menganalisis pendugaan parameter fungsi produksi stochastic frontier dan inefficiency function dilakukan secara simultan dengan program Frontier 4.1 (Coelli, 1996). Pengujian parameter stochastic frontier dan efek inefisiensi teknis dilakukan dengan dua tahap. Tahap pertama merupakan pendugaan parameter atau koefisien $\left(\beta_{\mathrm{i}}\right)$ dengan metode OLS menggunakan software SAS 9.6 untuk memeriksa adanya pelanggaran asumsi (multicolienarity, autocorellation dan heteroschedasticity), dan pelanggaran asumsi fungsi Cobb-Douglas pada fungsi produksi yang diduga. Tahap kedua merupakan pendugaan seluruh parameter $0, i$, varians $u_{i}$ dan $v_{i}$ dengan menggunakan metode Maximum Likelihood Estimation (MLE).

Fungsi produksi Stochastic Frontier CobbDouglas dengan metode MLE menghasilkan fungsi produksi yang telah fit, karena model tidak terjadi pelanggaran. Oleh karena itu, hasil pendugaan metode MLE ini meng- gambarkan kinerja terbaik (best practice) dari petani kedelai SLPTT dan non SLPTT. Nilai log likelihood function dengan metode MLE bernilai lebih besar $(-20,67)$ dibanding nilai $\log$ likelihood function OLS $(-29,15)$ yang menunjukkan bahwa model tersebut sesuai dan lebih baik, serta adanya kesesuaian dengan kondisi usahatani kedelai di Kabupaten Jember.

Hasil analisis model fungsi produksi Stochastic Frontier Cobb-Douglass dengan metode MLE dan software FRONTIER 4.1 menunjukkan semua variabel dugaan sebagai faktor produksi usahatani kedelai di Kabupaten Jember berpengaruh secara positif. Hasil analisis pendugaan menggunakan metode MLE diinformasikan pada Tabel 2. Persamaan model fungsi produksi stochastic frontier pada penelitian ini dapat dituliskan sebagai berikut:

$$
\begin{aligned}
\operatorname{Ln} Y= & \ln 61.70+0,25 \ln X_{1}+0,30 \ln X_{2}+0,09 \\
& \ln X_{3}+0,01 \ln X_{4}+0,22 \ln X_{5}+0,01 \ln \\
& X_{6}+0,10 \ln X_{7}+\left(v_{i}-u_{i}\right) \\
\operatorname{Ln} Y= & 4,12+0,25 \ln X_{1}+0,30 \ln X_{2}+0,09 \ln \\
& X_{3}+0,01 \ln X_{4}+0,22 \ln X_{5}+0,01 \ln X_{6} \\
& +0,10 \ln X_{7}+\left(v_{i}-u_{i}\right)
\end{aligned}
$$


Tabel 2. Hasil Analisis Pendugaan Fungsi Produksi Usahatani Kedelai dengan Metode MLE di Kabupaten Jember Tahun 2013

\begin{tabular}{|l|c|c|c|c|}
\hline \multicolumn{1}{|c|}{ Variabel input } & Parameter & Koefisien & St. Error & t-ratio \\
\hline Intersep & $\beta_{0}$ & 4,1223 & 0,7710 & 5,3478 \\
\hline Luas lahan (ha) & $\beta_{1}$ & $\left.0,2503^{* *}\right)$ & 0,1136 & 2,2046 \\
\hline Jumlah benih (kg) & $\beta_{2}$ & $\left.0,3048^{* \star *}\right)$ & 0,0867 & 3,5149 \\
\hline Jumlah pupuk kimia (kg) & $\beta_{3}$ & $\left.0,0922^{* *}\right)$ & 0,0224 & 4,1036 \\
\hline Jumlah pupuk organik (kg) & $\beta_{4}$ & 0,0076 & 0,0110 & 0,6627 \\
\hline Jumlah pestisida cair (ml) & $\beta_{5}$ & $\left.0,2164^{* \star *}\right)$ & 0,0833 & 2,5959 \\
\hline Jumlah ZPT (gr) & $\beta_{6}$ & 0,0072 & 0,1057 & 0,6848 \\
\hline Jumlah tenaga kerja (HOK) & $\beta_{7}$ & 0,0968 & 0,1139 & 0,8494 \\
\hline Log likelihood MLE & $-20,674$ & & & \\
\hline Log likelihood OLS & $-29,157$ & & &
\end{tabular}

Ket: $\left.{ }^{* * *}\right)$ Nyata pada a 1 persen dan ${ }^{* *}$ Nyata pada a 5 persen

Nilai koefisien pada Tabel 2 menunjukkan nilai elastisitas produksi usahatani kedelai di Kabupaten Jember. Berdasarkan hasil analisis, diketahui variabel penduga luas lahan $\left(\mathrm{X}_{1}\right)$ yang digunakan berpengaruh secara signifikan pada a 5 persen dan variabel penduga benih $\left(\mathrm{X}_{2}\right)$, pupuk kimia $\left(\mathrm{X}_{3}\right)$, serta pestisida cair $\left(\mathrm{X}_{5}\right)$ berpengaruh secara signifikan pada a 1 persen terhadap tingkat produksi usahatani kedelai di Kabupaten Jember. Tiga variabel penduga lainnya, yaitu variabel penggunaan pupuk organik $\left(X_{4}\right)$, jumlah ZPT $\left(X_{6}\right)$, dan tenaga kerja $\left(X_{7}\right)$ berpengaruh secara positif terhadap tingkat produksi usahatani kedelai di Kabupaten Jember, namun tidak signifikan pada a 1, 5, 10, atau pun 15 persen. Artinya, setiap penambahan ketiga variabel tersebut mampu meningkatkan produksi kedelai di Kabupaten Jember, namun tidak secara nyata.

Nilai koefisien variabel paling tinggi dibandingkan dengan variabel lainnya adalah variabel jumlah benih. Hal tersebut menunjukkan peningkatan nilai produksi kedelai di Kabupaten Jember sangat responsif terhadap penggunaan jumlah benih kedelai daripada variabel lainnya. Hal senada mengenai faktor benih yang sangat responsif terhadap produksi usahatani di luar negeri adalah Watkins (2013) dan Maganga (2011). Berbeda halnya dengan penelitian Jamhari et al. (2010) mengenai komoditas kedelai di Sulawesi Selatan yang menghasilkan faktor penggunaan benih kedelai bukan yang paling responsif, namun tetap berpengaruh secara positif dan nyata.

Penambahan penggunaan jumlah benih pada kegiatan usahatani kedelai di Kabupaten Jember sebesar $1 \%$ mampu meningkatkan nilai produksi kedelai sebesar $0.30 \%$ dalam asumsi variabel lain dalam keadaan cateris paribus dengan tingkat kepercayaan sebesar 99\%. Berdasarkan petunjuk teknis program SLPTT kedelai 2013 di Kabupaten Jember penggunaan benih adalah sekitar 40-60 kg per ha untuk meningkatkan produktivitas kedelai nasional. Berdasarkan data lapang dari 100 responden petani kedelai di Kabupaten Jember yang menggunakan jumlah benih kedelai sekitar 40-60 kg per hektar sebanyak 48 orang, penggunaan benih kedelai kurang dari $40 \mathrm{~kg}$ per ha sebanyak 23 orang, dan penggunaan benih kedelai lebih dari $60 \mathrm{~kg}$ per ha sebanyak 29 orang. Diketahui pada Tabel 1 penggunaan minimum jumlah benih kedelai per ha adalah $30 \mathrm{~kg}$ oleh petani SLPTT dan $16.67 \mathrm{~kg}$ per ha oleh petani non SLPTT. Dengan demikian, masih adanya kerasionalan dalam peningkatan penggunaan jumlah benih kedelai bagi petani yang penggunaannya jumlah benihnya kurang dari $40 \mathrm{~kg}$ per ha.

Variabel kedua yang berpengaruh secara nyata terhadap peningkatan produksi kedelai di Kabupaten Jember adalah luas lahan. Sama halnya dengan penelitian Taru et al. (2011) dengan pendekatan alat analisis yang sama. 
Berdasarkan karakterstik petani responden diketahui petani memanfaatkan luas lahan untuk usahatani kedelai sebanyak $52 \%$ pada rentang luas areal 0.10-0.50 ha. Petani yang memanfaatkan lahannya untuk usahatani kedelai di atas 1 ha hanya sebesar $12 \%$. Dengan demikian, adanya kerasionalan dalam memperluas areal tanam untuk usahatani kedelai.

Variabel pestisida cair yang berpengaruh meningkatkan produksi dan nyata, memiliki kerasionalan untuk ditambah. Namun jenis pestisida harus disesuaikan dengan OPT dan atau penyakit yang menyerang tanaman kedelai, serta perlunya penyesuaian intensitas dan waktu penyemprotan. Pada kondisi di lapang, tanaman kedelai mudah terserang ulat polong terutama bila waktu penanaman kedelai terlambat pada MK II seperti yang dialami oleh beberapa responden. Oleh sebab itu, perlunya pengendalian penyemprotan pestisida sampai 15 hari sebelum panen. Pestisida yang sering digunakan oleh petani pada lokasi penelitian merupakan persitisida yang berfungsi untuk memberantas serangan ulat grayak (Prodenia litura), ulat polong (Etiela zinchenella), serta penyakit karat daun (Cendawan phakospora phachyrizi), dan penyakit layu (Jamur tanah: Sclerotium rolfsii).

Pupuk kimia sebagai variabel berpengaruh keempat terhadap peningkatan produksi kedelai sama halnya dengan penelitian Essilfie (2011) dimana pupuk kimia mampu menaikkan output jagung sebesar 12 kg. Petani kedelai di Kabupaten Jember ratarata hanya menggunakana pupuk NPK Phonska. Selain itu, petani yang menggunakan variasi pupuk selain NPK Phonska tidak lebih dari 20 persen dari petani kedelai responden. Selain itu, menurut pedoman SLPTT menyatakan penggunaan pupuk NPK adalah $200 \mathrm{~kg}$ per ha, sedangkan pada keadaan di lapang petani rata-rata menggunakan kimia sebesar $95 \mathrm{~kg}$ per ha oleh petani SLPTT dan $73.41 \mathrm{~kg}$ oleh petani non SLPTT.

Variabel kelima yang berpengaruh secara positif namun tidak secara signifikan adalah penggunaan jumlah tenaga kerja senada pada pada hasil penelitian Chang et al. (2011). Para petani kedelai di Kabupaten Jember bekerjasama dalam pelaksanaan persiapan lahan dan pemberantasan hama. Hal ini yang mendukung pertambahan jumlah tenaga kerja dalam peningkatan poduksi kedelai tidak berpengaruh secara nyata terhadap produksi kedelai.

Variabel selanjutnya yang memengaruhi produksi kedelai secara positif dan tidak nyata adalah pupuk organik. Hal ini diduga pupuk organik tidak bekerja dengan baik terhadap kegunaannya secara fisik dalam memperbaiki pori-pori tanah dan agregatagregat tanah (Suteja 2002). Pada saat penanaman MT II 2013 diketahui hujan cukup deras, akibatnya drainase yang dangkal membuat airase tanah menjadi tidak lebih baik dan kemampuan akar dalam menyerap unsur hara menurun. Selain itu, rata-rata penggunaan pupuk organik per hektar oleh petani SLPTT sebanyak $570.88 \mathrm{~kg}$ dan petani non SLPTT $47.10 \mathrm{~kg}$, padahal berdasarkan petunjuk teknis SLPTT Kabupaten Jember penggunaan pupuk organik yang baik adalah $1000-2000 \mathrm{~kg}$ per ha. Oleh sebab itu, peningkatan persentase polong bernas tidak terlihat nyata. Selain itu, berdasarkan hasil wawancara didapat petani SLPTT yang mendapatkan bantuan pembelian pupuk organik untuk usahatani kedelai tidak dimanfaatkan pada usahatani kedelai, melainkan disimpan untuk usahatani padinya pada musim mendatang.

Variabel terakhir yang berpengaruh secara positif dan tidak nyata selanjutnya adalah zat pengatur tumbuh (ZPT). Penggunaan (ZPT) pada tanaman dipengaruhi oleh berbagai faktor seperti konsentrasi yang tepat dan waktu penyemprotan. Menurut Harjadi (2009), respon tanaman sebagai akibat pemberian ZPT bergantung pada bagian tumbuhan, fase perkembangan tanaman, konsentrasi ZPT, interaksi antar ZPT, dan faktor lingkungan. Pada kondisi di lapang diduga waktu pemberian ZPT yang kurang tepat, dimana waktu yang baik adalah pada siang hari. Pemberian ZPT pada siang hari dengan suhu tinggi berperan positif atau 
memacu kinerja ZPT itu sendiri. Namun, pada keadaan di lapang petani ada yang menyemprotnya pada pagi hari.

\section{ANALISIS EFISIENSI TEKNIS USAHATANI KEDELAI DI KABUPATEN JEMBER}

Efsiensi secara teknis pada kegiatan usahatani kedelai dapat tercapai bila petani mampu menghasilkan output maksimum dari sejumlah input yang digunakan dalam kegiatan usahatani. Menurut Khumbakar dan Lovel (2000) menyatakan fungsi produksi frontier merupakan output maksimum yang dapat diproduksi dari sejumlah input tertentu. Kondisi penggunaan input yang paling efisien pada titik-titik di sepanajng kurva produksi frontier pada kegiatan usahatani. Kegiatan usahatani yang dapat beroperasi pada titik batas (frontier), maka efisiensi teknis telah tercapai. Rata-rata tingkat efisiensi teknis telah tercapai pada titik 0,70 (Coelli et al., 2005).

Berdasarkan hasil analisis diketahui nilai Sigma-square $\left(\Sigma^{2}\right)$ sebesar 0,4245 menunjukkan distribusi dari error term inefisiensi teknis $\left(\mathrm{u}_{\mathrm{i}}\right)$ memiliki nilai yang mendekati nol, maka dinyatakan terdistribusi secara normal. Nilai Y sebesar 0,9052 dimana, nilai tersebut mendekati angka satu. Artinya, error term berasal dari akibat inefisiensi $\left(\mathrm{u}_{\mathrm{i}}\right)$ sebesar 90 persen dan 10 persen berasal dari akibat noise $\left(\mathrm{v}_{\mathrm{i}}\right)$.

\section{Sebaran Tingkat Efisiensi Teknis Usahatani Kedelai di Kabupaten Jember}

Usahatani kedelai yang mampu menghasilkan output maksimum dari sejumlah input tertentu yang digunakan disebut telah efisien secara teknis. Menurut Coelli et al. (2005) dan beberapa penelitian terdahulu menyatakan, rata-rata efisiensi teknik yang bernilai $\geq 0,70$ artinya, telah mencapai efisien secara teknis.

Tabel 3 menginformasikan bahwa, usahatani kedelai petani SLPTT sebanyak 88\% dan petani non SLPTT sebanyak $70 \%$ telah mencapai efisiensi teknis. Petani kedelai belum mencapai efisiensi secara teknis pada kegiatan usahataninya sebanyak $21 \%$ dengan sebaran efisiensi 0,30 hingga kurang dari 0,70. Sebanyak $79 \%$ usahatani kedelai di Kabupaten Jember telah efisien secara teknis.

Tabel 3. Sebaran Tingkatan Efisiensi Teknis Usahatani Kedelai di Kabupaten Jember 2013

\begin{tabular}{|c|c|c|c|c|c|c|}
\hline \multirow{2}{*}{ Sebaran efisiensi } & \multicolumn{2}{|c|}{ Petani SLPTT } & \multicolumn{2}{|c|}{ Petani non SLPTT } & \multicolumn{2}{|c|}{$\begin{array}{l}\text { Total Petani } \\
\text { Responden }\end{array}$} \\
\hline & $\begin{array}{l}\text { Jumlah } \\
\text { (orang) }\end{array}$ & $\begin{array}{c}\text { Presentase } \\
(\%)\end{array}$ & $\begin{array}{l}\text { Jumlah } \\
\text { (orang) }\end{array}$ & $\begin{array}{c}\text { Presentase } \\
(\%)\end{array}$ & $\begin{array}{l}\text { Jumlah } \\
\text { (orang) }\end{array}$ & $\begin{array}{c}\text { Presentase } \\
(\%)\end{array}$ \\
\hline $0.30 \leq \mathrm{TE}<0.40$ & 1 & 2 & 3 & 6 & 4 & 4 \\
\hline $0.40 \leq \mathrm{TE}<0.50$ & 0 & 0 & 4 & 8 & 4 & 4 \\
\hline $0.50 \leq \mathrm{TE}<0.60$ & 0 & 0 & 2 & 4 & 2 & 2 \\
\hline $0.60 \leq \mathrm{TE}<0.70$ & 5 & 10 & 6 & 12 & 11 & 11 \\
\hline Jumlah & 6 & 12 & 15 & 30 & 21 & 21 \\
\hline $0.70 \leq \mathrm{TE}<0.80$ & 7 & 14 & 8 & 16 & 15 & 15 \\
\hline $0.80 \leq \mathrm{TE}<0.90$ & 24 & 48 & 17 & 34 & 41 & 41 \\
\hline $0.90 \leq \mathrm{TE}<1.00$ & 13 & 26 & 10 & 20 & 23 & 23 \\
\hline Jumlah & 44 & 88 & 35 & 70 & 79 & 79 \\
\hline Total & 50 & 100 & 50 & 100 & 100 & 100 \\
\hline Efisiensi rata-rata & \multicolumn{2}{|c|}{0.83} & \multicolumn{2}{|c|}{0.75} & \multicolumn{2}{|c|}{0.79} \\
\hline Efisiensi Maksimum & \multicolumn{2}{|c|}{0.94} & \multicolumn{2}{|c|}{0.94} & \multicolumn{2}{|c|}{0.94} \\
\hline Efisiensi Minimum & \multicolumn{2}{|c|}{0.39} & \multicolumn{2}{|c|}{0.30} & \multicolumn{2}{|c|}{0.30} \\
\hline Sigma-quare $\left(\Sigma^{2}\right)$ & \multicolumn{2}{|l|}{0.42} & & & & \\
\hline Gamma $(\gamma)$ & \multicolumn{4}{|l|}{0.90} & & \\
\hline
\end{tabular}


Berdasarkan Tabel 3 diketahui rata-rata tingkat efisiensi teknis adalah 0,79 atau 79\%, artinya usahatani kedelai di Kabupaten Jember telah efisien secara teknis. Tingkat rata-rata efisiensi teknis petani kedelai SLPTT sebesar 0,83 dan sebesar 0,75 oleh petani non SLPTT. Tingkat efisiensi tertinggi yang dicapai oleh petani kedelai di Kabupaten Jember pada titik 0,94 oleh petani kedelai SLPTT atau pun non SLPTT.

Rata-rata tingkat efisiensi teknis terendah pada titik 0,30 oleh petani non SLPTT dan petani SLPTT sebesar 0,39 di Kabupaten Jember. Adanya peluang untuk meningkatkan efisiensi teknis usahatani kedelai sebesar 21\% di Kabupaten Jember.

\section{Faktor-faktor yang Memengaruhi Efisiensi Teknis Usahatani Kedelai di Kabupaten Jember}

Faktor inefisien merupakan errror term $\left(\mathrm{u}_{\mathrm{i}}\right)$ dari fungsi produksi yang dihasilkan secara simultan melalui estimasi fungsi produksi metode MLE dengan model pendugaan fungsi produksi stochastic frontier Cobb-Douglas. Fungsi inefisiensi teknis ditentukan oleh manajerial petani, maka fungsi dari variabel penjelas di luar penggunaan input-input produksi. Sumbersumber inefisiensi teknis usahatani kedelai di Kabupaten Jember merupakan faktor efisiensi teknis yang digunakan sebagai variabel penduga dalam memengaruhi peningkatan jumlah produksi kedelai.

Faktor-faktor yang diduga memengaruhi efisiensi teknis kedelai meliputi karakteristik petani kedelai responden dan komponen SLPTT komoditas kedelai 2013 di Kabupaten Jember. Faktor-faktor tersebut terterdiri dari 10 variabel penjelas antara lain, usia petani kedelai $\left(Z_{1}\right)$, lama pendidikan formal $\left(Z_{2}\right)$, lama berusahatani kedelai $\left(Z_{3}\right)$, dummy teknik tanam $\left(Z_{4}\right)$, dummy penggunaan VUB $\left(Z_{5}\right)$, dummy penggunaan benih berlabel $\left(Z_{6}\right)$, dummy pengendalian mekanis $\left(\mathrm{Z}_{7}\right)$, jumlah kedatangan penyuluhan atau SLPTT $\left(\mathrm{Z}_{8}\right)$, dummy pernah mengikuti penyuluhan kedelai $\operatorname{SLPTT}\left(Z_{9}\right)$, jumlah bantuan usahatani kedelai $\operatorname{SLPTT}\left(Z_{10}\right)$.
Hasil analisis pada Tabel 4 menjelaskan nilai $\sum^{2}$ (sigma square) cukup kecil yaitu 0,42 , sehingga dapat disimpulkan bahwa error term inefisiensi pada usahatani kedelai di Kabupaten Jember terdistribusi normal. Jika tidak terjadi demikian, maka parameter koefisien inefisiensi menjadi tidak berarti. Nilai gamma ( $\gamma$ ) yang didapat sebesar 0,90, artinya sebesar 90 persen persamaan model yang diduga juga dipengaruhi oleh sumber inefisiensi $\left(u_{i}\right)$ dan sisanya sebesar 10 persen, produksi usahatani kedelai dipengaruhi faktor noise effect $\left(\mathrm{v}_{\mathrm{i}}\right)$. Noise effect atau faktor yang tidak dapat dikendalikan tersebut pada daerah penelitian, seperti hujan pada awal penanaman, hama tikus, dan ulat. Oleh karena itu, analisis terkait faktor-faktor efisiensi teknis tersebut dapat dijelaskan dari efek inefisiensi.

Berdasarkan Tabel 4 diketahui bahwa tidak semua faktor-faktor yang diduga dan ada pada model berpengaruh nyata pada tingkat signifikansi tertentu terhadap efisiensi usahatani kedelai di Kabupaten Jember. Hal ini berarti, ada beberapa fenomena di lapangan yang awalnya diduga memengaruhi efisiensi ternyata setelah dianalis tidak berpengaruh nyata terhadap efisiensi teknis usahatani kedelai di Kabupaten Jember. Hasil pendugaan dengan metode MLE menunjukkan variabel yang berpengaruh secara positif dan signifikan terhadap peningkatan efisiensi teknis meliputi, usia $\left(\mathrm{Z}_{1}\right)$, dummy teknik tanam $\left(\mathrm{Z}_{4}\right)$, dummy penggunaan VUB $\left(\mathrm{Z}_{5}\right)$, dummy pengendalian mekanis $\left(Z_{7}\right)$, dan jumlah kedatangan penyuluhan atau SLPTT $\left(Z_{8}\right)$.

Hipotesa pada nilai koefisien variabel penduga usia atau umur adalah positif. Artinya, semakin bertambah usia petani, maka tingkat efisiensi teknis semakin menurun karena semakin lemahnya kekuatan fisik. Namun, berdasarkan hasil analisis pada Tabel 3 didapat sebaliknya. Semakin bertambahnya usia petani kedelai di Kabupaten Jember, maka tingkat efisiensi teknis usahatani kedelai semakin meningkat dan berpengaruh nyata. 
Tabel 4. Hasil Pendugaan Inefisiensi Teknis Usahatani Kedelai di Kabupaten Jember 2013

\begin{tabular}{|c|c|c|c|c|}
\hline Variabel input & Parameter & Koefisien & St. Error & t-ratio \\
\hline Intersep & $Z_{0}$ & 1,3952 & 0,6724 & 2,0750 \\
\hline Usia petani kedelai (thn) & $Z_{1}$ & $-0,0246$ *) & 0,0177 & $-1,3843$ \\
\hline Lama pendidikan formal (thn) & $Z_{2}$ & $-0,0128$ & 0,0312 & $-0,4122$ \\
\hline Lama berusahatani kedelai (thn) & $Z_{3}$ & 0,0089 & 0,0145 & 0,6130 \\
\hline Dummy teknik tanam (tugal $=1$ ) & $Z_{4}$ & $-0,3340 *)$ & 0,2288 & $-1,4596$ \\
\hline Dummy penggunaan VUB & $Z_{5}$ & $\left.-0,5638^{*}\right)$ & 0,3661 & $-1,5397$ \\
\hline $\begin{array}{l}\text { Dummy penggunaan benih berlabel } \\
\text { (label = 1) }\end{array}$ & $Z_{6}$ & 0,0303 & 0,2794 & $-0,1085$ \\
\hline Dummy pengendalian mekanis & $Z_{7}$ & $-0,6134$ *) & 0,4288 & 1,4305 \\
\hline $\begin{array}{l}\text { Jumlah mengikuti penyuluhan dan atau } \\
\text { SLPTT kedelai } 2013 \text { (kali) }\end{array}$ & $Z_{8}$ & $\left.-0,3056^{*}\right)$ & 0,2198 & $-1,3904$ \\
\hline $\begin{array}{l}\text { Dummy pernah mengikuti penyuluhan } \\
\text { dan atau SLPTT kedelai sebelum } 2013 \\
\text { (pernah = 1) }\end{array}$ & $Z_{9}$ & $-0,1779$ & 0,3012 & $-0,5905$ \\
\hline Jumlah bantuan usahatani kedelai (Rp) & $Z_{10}$ & 0,0000 & 0,0000 & $-0,3023$ \\
\hline Sigma square $\left(\sum^{2}\right)$ & 0,42 & & & \\
\hline Gamma $(\gamma)$ & 0,90 & & & \\
\hline
\end{tabular}

Ket: *) Nyata pada taraf a $10 \%$

Hasil penelitian ini sejalan dengan penelitian Essilfie (2011), Fernandez dan Nuthall (2009), serta Gul et al. (2009) yang menyatakan semakin bertambahnya usia, maka suatu usahatani semakin efisien secara teknis. Berbagai alasan dikemukakan, seperti adanya dukungan faktor pengalaman dan pendidikan seiring bertambahnya usia.

Hasil analisis mengenai variabel usia ini juga didukung oleh penelitian Göbel dan Zwick (2009) yang menyatakan bahwa produktivitas akan semakin meningkat seiring dengan bertambahnya usia pekerja pada usia 50-55 tahun (usia produktif). Petani kedelai di Kabupaten Jember diketahui sebesar $83 \%$ pada kategori usia produktif dan dari petani usia produktif tersebut sebanyak $59 \%$ merupakan petani terampil dalam melaksanakan sistem tanam sesuai dengan pedoman teknis SLPTT, yaitu dengan sistem tugal. Hal ini yang mendukung faktor usia pada penelitian ini berpengaruh secara nyata terhadap efisiensi teknis usahatani kedelai di Kabupaten Jember.

Pada penelitian ini didapat faktor lama atau pengalaman berusahatani kedelai memiliki nilai koefisien yang positif. Artinya, semakin lama pengalaman berusahatani kedelai maka, semakin tidak efisien secara teknis, namun diketahui tidak secara nyata. Hal ini diduga, petani belum tentu menjalankan atau menggunakan teknologi usahatani kedelai yang telah diperoleh atau bahkan petani kurang bersedia untuk mengadopsi ide-ide baru tersebut, baik itu melalui informasi penyuluhan perkedelaian dan atau SLPTT kedelai yang pernah diikuti. Sejalan dengan pernyataan Killic et al. (2009) mengenai efisiensi teknis hazelnut di Turki yang menyatakan hubungan antara umur petani seiring bertambahnya pengalaman terhadap efisiensi teknis adalah sebuah apriori tak tentu.

Fenomena di lapang didapat petani SLPTT tidak memanfaatkan pupuk organik dan atau mengurangi dosis ketentuan pemberian pupuk organik pada usahatani kedelai yang telah diperoleh dari dana bantuan SLPTT. Diketahui petani SLPTT ratarata menggunakan pupuk organik $570.88 \mathrm{~kg}$ (Tabel 1), dimana petunjuk teknis SLPTT kedelai di Kabupaten Jember menyarankan penggunaan pupuk organik sebesar 1.000$2.000 \mathrm{~kg}$ per ha. Berdasarkan Tabel 4 diketahui variabel pengalaman juga tidak signifikan. Jadi, tidak dapat ditarik suatu kesimpulan bahwa pengalaman benar-benar menurunkan efisiensi teknis. 
Hasil dari variabel pengalaman, sejalan dengan hasil variabel pernah atau tidaknya mengikuti penyuluhan dan atau SLPTT kedelai sebelum tahun 2013 yang tidak nyata berpengaruh dalam peningkatan efisiensi teknis usahatani kedelai. Petani yang pernah mengikuti penyuluhan perkedelaian dan atau SLPTT kedelai sebelum tahun 2013 sebanyak $70 \%$ dan diantaranya yang melaksanakan komponen SLPTT sistem tugal sebanyak $65,71 \%$ telah efisien, sisanya menggunakan sistem sebar. Selain karena sudah menjadi kebiasaan dan kemudahan terhadap sistem sebar yang menjadi alasan petani ini, sistem sebar mampu meminimalisir jumlah tenaga kerja yang tentunya terkait dengan penekanan upah tenaga keja. Variabel pengalaman dan variabel pernah atau tidaknya mengikuti penyuluhan perkedelaian dan atau SLPTT kedelai sebelum 2013 tidak dapat disimpulkan menurunkan atau menaikkan, karena secara statistika tidak signifikan.

Petani melalui pendidikan yang lebih tinggi, diindikasikan lebih mampu dalam mengambil suatu keputusan manajerial. Fenomena di lapang sebanyak $49 \%$ petani kedelai di Kabupaten Jember pada pendidikan di atas SD (SMP, SMA, dan perguruan tinggi) dan diketahui $87.76 \%$ usahatani kedelainya telah efisien secara teknis. Berbeda dengan pernyataan Killic et al. (2009) mengenai variabel pendidikan formal yang memiliki pengaruh negatif terhadap peningkatan efisiensi teknis. Hal ini yang menyebabkan variabel usia, pengalaman berusahatani kedelai, dan pendidikan petani kedelai pada setiap penelitian bersifat inclonsive atau belum konsisten.

Variabel lainnya yang berpengaruh secara nyata terhadap peningkatan efisiensi teknis adalah teknik tanam, penggunaan benih varietas unggul baru (VUB), dan pengendalian mekanis. Berdasarkan petunjuk teknis SLPTT di Kabupaten Jember sistem tanam yang sesuai dengan keadaan agronomis adalah sistem tugal. Namun hanya $60 \%$ petani yang menggunakan sistem tugal, sisanya menggunakan sistem sebar. Petani yang menggunakan sistem tugal sebanyak
$87,88 \%$ telah efisien secara teknis. Penggunaan benih kedelai VUB sebanyak 66\% petani dan 91\% usahataninya telah efisien secara teknis. Petani yang melakukan pengendalian mekanis sebanyak $54 \%$ petani dan sebesar $87,04 \%$ usahatani kedelainya telah efisien secara teknis.

Penggunaan benih berlabel merupakan benih bermutu yang diharapkan memiliki tingkat kemurnian dan daya tumbuh tinggi karena lolos proses sertifikasi, sehingga efisiensi teknis tercapai. Namun, berdasarkan hasil analisis variabel penggunaan benih berlabel mampu menurunkan efisiensi. Berdasarkan hasil wawancara, petani menyatakan benih berlabel yang didapat dari PT Sang Hyang Seri (SHS) memiliki kelembapan di luar standar (biji terlalu lunak). Hal ini diindikasikan benih terlalu lama pada gudang produsen, sehingga benih sudah melebihi masa dormansi yang hanya 3 bulan.

Petani yang mengikuti penyuluhan dan atau SLPTT kedelai pada tahun musim tanam (2013) menunjukkan sangat berpengaruh secara nyata terhadap peningkatan efisiensi teknis. Hal ini diduga semakin banyak (lebih dari 2 kali) mengikuti kegiatan penyuluhan dan atau SLPTT kedelai saat musim tanam, petani masih bersemangat dan mengingat informasi yang disampaikan, sehingga terjadi transfer teknologi lebih baik dibanding hanya suatu pengalaman dan pernahnya mengikuti penyuluhan atau pun SLPTT kedelai. Ratarata petani yang demikian, memiliki tingkat efisiensi teknis di atas 0,70, sedangkan yang tidak mencapai efisiensi tersebut jumlah mengikutinya tidak lebih dari 2 kali disertai tidak memanfaatkan pupuk organik dan penanaman sistem tugal.

Variabel bantuan dana SLPTT menunjukkan semakin tinggi dana yang diberikan, maka semakin tidak efisien ssecara teknis, namun tidak signifikan. Hal ini diduga adanya fenomena sosial seperti, penyaluran benih kedelai pada petani yang telah dibeli dari dana bantuan dan ketentuan SLPTT datang terlambat. Keterlambatan penanaman kedelai harus dihindari agar tanaman tidak 
mudah terserang ulat polong, sehingga petani membeli benih pada petani lain di daerah lain yang sudah panen atau kepada jabal (jalinan benih antar lapang) agar menanam tepat waktu. Selain itu, adapun $20 \%$ petani yang tidak menggunakan keseluruhan input pupuk organik atau mengurangi dosis pupuk organik pada usahatani kedelai, dikarenakan petani ingin menggunakannya pada usahatani padi di musim padi mendatang pada MK I.

Bantuan langsung tanpa adanya pengembalian seperti ini tanpa adanya pengawasan ketat serta kurangnya kerjasama stakeholder (khususnya penyuluh terhadap petani yang tidak memanfaatkan bantuan input untuk usahatani kedelai dan penyedia serta penyalur input benih) diindikasikan yang menyebabkan variabel bantuan SLPTT mampu menurunkan efisiensi teknis. Namun, berdasarkan hasil analisis variabel bantuan SLPTT tidak berpengaruh menurunkan efisiensi teknis secara nyata, sehingga tidak dapat ditarik suatu kesimpulan mengenai variabel tersebut.

Berbeda halnya dengan Bantuan Pinjaman Langsung Masyarakat (BPLM) yang diteliti oleh Mariyah (2009). Ia menyatakan koefisien variabel BPLM bernilai negatif dan nyata terhadap inefisiensi teknis. Artinya, ketersediaan BPLM dapat menghilangkan kendala produksi dalam memperoleh input pada saat yang tepat dan dapat meningkatkan efisiensi teknis petani padi. Dana BPLM cenderung digunakan petani padi di Kabupaten Penajam Paser untuk penggunaan sarana produksi agar mendapatkan hasil yang baik, sehingga dapat mengembalikan dana pinjaman dan meningkatkan pendapatan.

\section{KESIMPULAN DAN SARAN}

\section{KESIMPULAN}

Berdasarkan hasil penelitian, analisis, dan pembahasan dalam mencapai tujuan penelitian ini, maka simpulan dari penelitian tersebut sebagai berikut:
1. Faktor-faktor yang memengaruhi produksi kedelai di Kabupaten Jember tahun 2013 secara signifikan antara lain, luas lahan, benih, pupuk kimia, dan obat-obatan cair. Produksi kedelai paling responsif terhadap faktor penggunaan jumlah benih kedelai.

2. Usahatani kedelai baik petani SLPTT dan non SLPTT di Kabupaten Jember telah efisien secara teknis dengan nilai 0,79 dan tingkat efisiensi teknis usahatani kedelai petani SLPTT lebih tinggi dibanding petani non SLPTT (masing-masing bernilai 0,83 dan 0,75$)$.

3. Faktor-faktor yang memengaruhi dan signifikan terhadap peningkatan efisiensi teknis usahatani kedelai di Kabupaten Jember tahun 2013 antara lain, usia, dummy teknik tanam, dummy penggunaan benih kedelai VUB, dummy pengendalian mekanis, serta dummy kedatangan jumlah penyuluhan dan atau SLPTT kedelai 2013.

\section{SARAN}

Berdasarkan hasil wawancara, analisis, dan pembahasan, maka beberapa saran dari penelitian tersebut antara lain sebagai berikut: 1. Penggunaan pupuk organik yang dibeli dari dana program SLPTT usahatani kedelai disarankan untuk benar-benar dimanfaatkan pada usahatani kedelai bukan untuk kegiatan usahatani padi.

2. Bagi petani non SLPTT perlunya menerima program SLPTT agar tingkat efisiensi lebih tinggi dan lebih banyak petani yang mencapai efisien secara teknis dalam kegiatan usahatani kedelainya.

3. Pembenahan faktor manajerial petani yang berpengaruh positif dan signifikan terhadap peningkatan efisiensi teknis. Contohnya, petani yang belum menggunakan benih VUB sebaiknya menggunakan, petani yang belum melakukan pengendalian mekanis sebaiknya melakukan, dan petani disarankan untuk selalu mengikuti program penyuluhan dan atau SLPTT kedelai yang telah difasilitasi. 
4. Perlunya monitoring ketat dari dinas pertanian daerah dalam mengawasi petugas penyaluran input khususnya benih dengan adanya sanksi tegas bagi petugas, sehingga penyaluran input tidak terlambat.

\section{DAFTAR PUSTAKA}

[BPS] Badan Pusat Statistika. 2013. Perkembangan Beberapa Indikator Utama Sosial-Ekonomi Indonesia. 3101015: Katalog BPS.

Coelli TJ, Rao DSP, J O'Donnell C, Battese GE. 2005. An Introduction of Efficiency and Productivity Analysis. 2nd Edition. New York: Springer.

Chang KLM, Lone TA, Langelett G. 2011. The Efficiency of Labor Input in The Tree Nut Industry : A Stochastic Frontier Production Approach Study in Buttecounty, California. African Journal of Business Management. 5 (7): 2618-2646.

Deputi Kacang dan Umbi. 2012. Kedelai. Jakarta (ID): Direktur Kacang dan Umbi Pr.

Dinas Pertanian. 2008. Laporan Pertanggungjawaban Program SLPTT. Jakarta (ID): Dinas Provinsi Jawa Barat.

Direktorat Jenderal Tanaman Pangan (2012). Pedoman Teknis Pengelolaan Produksi Kedelai Tahun 2013. Jakarta (ID): Kementerian Pertanian.

Elibariki E, Msuya, Shuji H, Tatsuhiko N. 2008. Explaining Productivity Variation among Smallholder Maize Farmers in Tanzania. Koreo : Paper was presented in the XII world congress of rural sociology of the international rural sociology association. Japan: Gonyang.

Essilfie FL, Asiamah MT, Nimoh F. 2011. Estimation of Farm Level Technical Efficiency in Small Scale Maize Production in The Mfantseman Municipality in The Central Region of Ghana: A Stochastic Frontier Approach. Journal of Development and Agricultural Economics..3 (14): 645-654.
Farrell MJ. 1957. The Measurement of Production Efficiency. Journal of The Royal Statiscal Socety. 120: 253-290.

Fernandez MDP, Nuthall L. 2009. Technical Efficiency in The Production of Sugar Cane In Central Negros Area, Philippines: An Application of Data Envelopment Analysis. Journal ISSAAS .15 (1) : 77-90.

Gul M, Koc B, Ddagistan E, Akpinar MG, Parlakay O. 2009. Determination of Technical Efficiency in Cotton GrowingFarms in Turkey: A case study of Cukurova region. African Journal of Agricultural Research. 4 (10): 77-90.

Göbel C, Zwick T. Age and Productivity: Evidence From Linked Employer Employee Data. ZEW Discussion Papers. 4 (2009) : 9-20.

Harjadi SS. 2009. Zat Pengatur Tumbuh: Pengenalan dan Petunjuk Penggunaan pada Tanaman. Jakarta (ID): Penebar Swadaya.

Harsono A. 2008. Strategi Pencapaian Swasembada Kedelai Melalui Perluasan Areal Tanam di Lahan Kering Masam. Iptek Tanaman Pangan. 3 (2).

Jamhari, Abdul GT, Dwidjono HD, Jangkung HM. 2010. Analisis Efisiensi Produksi Sistem Usahatani Kedelai di Sulawesi Selatan. Jurnal Agro Ekonomi. (2) 28: 133151.

Kementerian Pertanian. 2013. Swasembada Kedelai 2014. Jakarta (ID): Direktorat Jenderal tanaman Pangan.

Killic O, Binici T, Zulauf CR. 2009.Assessing the Efficiency of Hazelnut Production. African Journal of Agricultural Research. 4 (8): 695-700.

Kumbhakar SC, Lovell CAK. 2000. Stochastic Frontier Analysis. United Amerika Serikat (USA): Cambridge University Pr.

Maganga A.M. 2012. Technical Efficiency and Its Determinants in Irish Potato Production: Evidence from Dedza District, Central Malawi. Affrican Journal of Agricultural Research. 7 (12): 1795-1799. 
Mariyah. 2009. Pengaruh Bantuan Pinjaman Langsung Masyarakat Terhadap Pendapatan dan Efisiensi Usahatani Padi Sawah di Kabupaten Penajam Paser. EPP. (6) 1: 9-16.

Suteja. 2002. Pupuk dan Cara pemupukan. Jakarta (ID): PT Rineka Cipta.

Taru VB, Lawal H, Thize L. 2011.Technical Efficiency of Sole Cowpea Production in Adamawa State, Nigeria: A CobbDouglas Stochasticfrontier Function. Journal of Economics and International Finance. 3 (8): 504-507.

Watkins KB, Hristovska T, Mazzanti R, Wilson CE Jr. 2013. Measuring Technical, Allocative, and Economic Efficiency of Rice Production in Arkansas using Data Envelopment Analysis. Arkansas: University of Arkansas Rice Research and Extention Center. 
